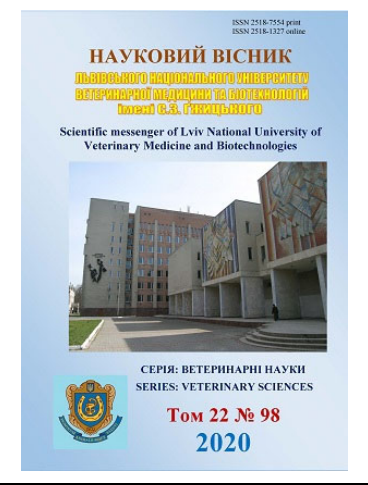

\author{
Науковий вісник Дьвівського національного університету \\ ветеринарної медицини та біотехнологій імені С.З. Гжицького. \\ Серія: Ветеринарні науки \\ Scientific Messenger of Lviv National University \\ of Veterinary Medicine and Biotechnologies. \\ Series: Veterinary sciences
}

UDC 619:614.7:636.4

\title{
Hygienic assessment of water quality and its impact on the body of pigs
}

\author{
N. U. Krempa ${ }^{1}$, O. V. Kozenko ${ }^{1}$, N. V. Chornyi ${ }^{2}$ \\ ${ }^{1}$ Stepan Gzhytskyi National University of Veterinary Medicine and Biotechnologies Lviv, Ukraine \\ ${ }^{2}$ Kharkov State Zooveterinary Academy, M. Danilovka, Dergachivsky district, Kharkiv region, Ukraine
}

Article info

Received 05.03.2020

Received in revised form 08.04 .2020

Accepted 09.04.2020

Stepan Gzhytskyi National University of Veterinary Medicine and Biotechnologies Lviv, Pekarska Str., 50, Lviv, 79010, Ukraine.

Tel.: +38-098-588-83-88 E-mail:krempanadia@ukr.net

Kharkov State Zooveterinary Academy, M. Danilovka, Dergachivsky district, Kharkiv region, Ukraine.
Krempa, N. U., Kozenko, O. V., \& Chornyi, N. V. (2020). Hygienic assessment of water quality and its impact on the body of pigs. Scientific Messenger of Lviv National University of Veterinary Medicine and Biotechnologies. Series: Veterinary sciences, 22(98), 9-15. doi: 10.32718/nvlvet9802

The results of research on the overall impact of drinking water quality, microclimate parameters and adopted in the farms of FE PE "Hlyniany Agro" and LLC "Miasni Resursy" options for growing weaned young (single- and three-phase) on morphological and biochemical parameters of blood, the level of natural resistance and their growth indicates that single-phase cultivation is more favorable for the growth and development of young animals. This is confirmed by the live weight of animals at birth and at the age of 120 days. Thus, in the case of single-phase cultivation of FE PE "Glynyany Agro" the live weight of piglets at birth was $1.11 \mathrm{~kg}$, and in the case of three-phase LLC "Miasni Resursy" - $1.07 \mathrm{~kg}$. When the animals reached 120 days of age, the live weight of piglets was $53.2 \mathrm{~kg}$ in FE PE "Glynyany Agro" and $50.2 \mathrm{~kg}$ in LLC "Miasni Resursy". It should be noted that according to most indicators, water quality in both farms is within acceptable limits of sanitary and hygienic requirements, although it needs to be improved. With regard to microclimatic indicators, an overestimated level of ammonia was found in FE PE "Glynyany Agro", which exceeded the MPC by 6 and $3.33 \mathrm{mg} / \mathrm{m}^{3}$, respectively, in the lines and transition periods, and in LLC "Miasni Resursy" was close to its upper borders. In a farm with single-phase animal husbandry, a slight decrease in erythrocytes in the blood of piglets aged 30 and 60 days was found. Since the animals reached the 120th day of life, an increase in this indicator was noted and the number of erythrocytes in the blood of animals of both farms, within the physiological norm, was 6.47 T/l (FE PE "Hlyniany Agro") and $7.31 \mathrm{~T} / \mathrm{l}$ (Miasni Resursy LLC). The concentration of hemoglobin was low in animals of both farms, but the highest rates were in animals of FE PE "Hlyniany Agro" at 30 and 60 days of age, and at 120 days of age this figure $(3.28 \mathrm{~g} / \mathrm{l})$ was higher already in piglets of Miasni Resursy LLC. The content of total protein in the blood of piglets from both farms was also low, but by the time the animals reached 120 days of age, it was already within the physiological norm. Violation of the albumin-globulin ratio with the vast majority of globulins was also noted. Regarding cellular immunity, it was noted that the content of T-lymphocytes only in animals 120 days of age was normal, exceeding the lower limit of physiological norm by $0.27 \%$ in animals with FE PE "Hlyniany Agro" and $2.09 \%$ in animals with Miasni Resursy LLC. Our research once again confirms that the health, growth, development, and productivity of animals are influenced by a number of factors, both hygienic and technological.

Key words: piglets, blood, water quality, microclimate, housing conditions.

\section{Гігієнічна оцінка якості води та їі вплив на організм свиней}

\author{
Н. Ю. Кремпа ${ }^{1}$ О. В. Козенко ${ }^{1}$ М. В. Чорний ${ }^{2}$
}

${ }^{1}$ Львівський національний університет ветеринарної медицини та біотехнологій імені С. 3. Гэсицького, м. Львів, Україна

${ }^{2}$ Харківська державна зооветеринарна академія, м. Харків, Україна 
Отримані результати досліджень сукупного впливу якості питної води, параметрів мікроклімату та прийнятих в господарствах ФГ ПП “Глиняни Агро” та ТзОВ “М'ясні ресурси” варіантів вирощування відлученого молодняку (одно- та трифазне) на морфологічні та біохімічні показники крові, рівень природної резистентності та їхні прирости вказують на те, щзо однофазне вирощування сприятливіше для росту та розвитку молодняку. Підтвердженням цьвого слугують показники живої маси тіла тварин при народженні та у вічі 120 діб. Так, за однофазного вирошування ФГ ПП “Глиняни Агро” жсива маса поросяти при народженні становила 1,11 к2, а за трифазного ТзОВ “М'ясні ресурси”- 1,07 кг. При досягненні тваринами 120-добового віку, жива маса поросяти становила 53,2 кг у ФГ ПП “Глиняни Агро” та 50,2 кг у ТзОВ “М'ясні ресурси”. Варто відмітити, щзо за більшістю показників якість води в обох господарствах - в допустимих межах санітарно-гігієнічних вимог, хоча й потребує покращення. Стосовно мікрокліматичних показників, то встановлено завищений рівень аміаку у ФГ ПП “Глиняни Агро”, який перевищував ГДК на 6 та 3,33 мг/м³ відповідно у ліній та перехідні періоди, а в ТзОВ “М'ясні ресурси” був наближеним до ії верхньої межі. У господарстві з однофазним вирощуванням тварин установлено незначне зниження еритрочитів в крові поросят 30- та 60-добового віку. 3 досягнення тваринами 120-ї доби життя відмічено зростання цьього показника і кількість еритроцитів у крові тварин обох господарств, вкладаючись в межі фізіологічної норми, становила 6,47 Т/л (ФГ ПП “Глиняни Агро”) та 7,31 Т/л (ТзОВ “М'ясні ресурси”). Концентрачія гемоглобіну була низькою у тварин обох господарств, проте вищими показники були у тварин ФГ ПП “Глиняни Агро”" у 30- та 60-добовому віці, а у 120-добовому віці ией показник (на 3,28 г/л) був більшим вже у поросят ТзОВ “М'ясні ресурси”. Низьким виявився і вміст загального білка у крові поросят обох господарств, проте з досягненням тваринами 120-добового віку він вже вкладався в межі фізіологічної норми. Відмічено також порушення альбуміно-глобулінового співвідношення з переважаючою більшістю глобулінів. Щодо показників клітинного імунітету, відмічено, щзо вміст Т-лімфоцитів лише у тварин 120-добового віку відповідав нормі, перевищуючи нижню межу фізіологічної норми на 0,27 \% у тварин з ФГ ПП “Глиняни Агро” та на 2,09 \% у тварин з ТзОВ “М'ясні ресурси”. Проведені нами дослідження щче раз підтверджують, щзо на здоров 'я, ріст, розвиток, продуктивність тварин впливає сума факторів як гігієнічного, так і технологічного спрямування.

Ключові слова: поросята, кров, якість води, мікроклімат, умови утримання.

\section{Вступ}

Вода як один із найважливіших факторів повноцінної життєдіяльності живих організмів бере участь у всіх біологічних процесах. Фізіологічне значення води полягає в іiї здатності виконувати функцію носія, як поживних речовин, так і виведення продуктів обміну - токсинів. Вона сприяє здійсненню процесів асиміляції, дисиміляції, дифузії, осмосу, окиснення, гідролізу, регулювання теплообміну в організмі. За сучасних методів ведення господарської діяльності дуже важливо забезпечити тварин якісною водою, що дасть можливість створити оптимальні умови для здійснення фізіологічних процесів в організмі, а також сприятиме підтриманню на належному рівні санітарно-гігієнічного стану як тварин, так і приміщень для їх утримання (Zapolskyi, 2005; DSTU 4808:2007).

Актуальність теми. Гігієнічне значення води визначається не тільки їі кількістю, а й якістю, вона має бути бездоганною в санітарному відношенні, це встановлюють за органолептичними властивостями, хімічним складом і відсутністю в ній збудників інфекційних та інвазійних хвороб відповідно до вимог стандарту (DSTU 7525:2014; Hryhorenko, 2015; Ievtushenko \& Dudnyk, 2016; Goryaev et al., 2016; Kelly et al., 2020).

Особливо чутливі до безперебійного водопостачання високопродуктивні тварини та молодняк. Доведено, що навіть при незначних порушеннях у забезпеченні організму водою різко знижується продуктивність, сповільнюється ріст і розвиток молодняку. Молодому організму на 1 кг живої маси потрібно удвічі більше води, ніж дорослому (Anush, 1979; Demchuk et al., 2006). Споживання води залежить від виду, віку, продуктивності та використання тварин, а також від типу годівлі, фізичного стану згодовуваних кормів, їхньої якості та метеорологічних умов.

Вода, призначена для напування тварин, за своєю якістю (прозорість, колірність, відсутність запаху, присмаку, відсутність хвороботворних бактерій) має відповідати загальноприйнятим нормам щодо води, призначеної для людей (DSTU 4808:2007; Zahalnoderzhavna prohrama..., 2012).

На рівень споживання води тваринами, особливо молодняком, вагомий вплив має температура навколишнього середовища та умови утримання загалом. Недотримання фізіологічних принципів напування i санітарно-гігієнічних вимог часто буває причиною зниження продуктивності та розвитку захворювань тварин, що негативно відображається на рентабельності господарства (Harytskyi \& Rozumniuk, 2007; Tkachuk, 2010).

Метою наших досліджень було вивчити сукупний вплив якості питної води, параметрів мікроклімату та прийнятого в господарстві варіанту вирощування відлученого молодняку (одно- та трифазне) на морфологічні та біохімічні показники крові, рівень природної резистентності, збереженість поросят та їхні прирости.

\section{Матеріал і методи досліджень}

Дослідження проводили у двох господарствах: ФГ ПП "Глиняни Агро" Золочівського району та ТзОВ "М'ясні ресурси” Старосамбірського району. Обидва господарства розташовані у Львівській області та спеціалізуються на виробництві свинини. Технологічна різниця у виробництві даної продукції полягає у фазності вирощування поросят. ФГ ПП “Глиняни Агро" практикує однофазне вирощування, тимчасом як ТзОВ “М'ясні ресурси" застосовують трифазне вирощування. Для порівняльної оцінки умов вирощування у кожному господарстві було сформовано групу поросят-аналогів по 11 голів.

Дослідження якості води, морфологічних та біохімічних показників крові проводили в навчальній лабораторії кафедри гігієни, санітарії та загальної ветеринарної профілактики ЛНУВМБ імені С. З. Гжицького та у лабораторії промислової токсикології ЛНМУ імені Д. Галицького, де визначали рівень клітинного 
імунітету. Зокрема, у воді визначали: прозорість, запах, смак і присмак, окислюваність та вміст розчиненого кисню, активну реакцію, вміст амонійного азоту, нітритів, нітратів, хлоридів, сульфатів, заліза, загальну, карбонатну та постійну твердість. У зразках крові визначали кількість еритроцитів, концентрацію гемоглобіну, гематокритну величину, КП, СОЕ та ШОЕ; концентрацію загального білка та білкових фракцій, показники клітинного імунітету (вміст Т- i Bлімфоцитів та їх популяцій), за загальноприйнятими методиками.

Поряд з вищенаведеними показниками проводили контроль параметрів мікроклімату.

Отримані числові дані опрацьовували статистично 3 використанням комп'ютерної програми Statist. Peзультати середніх значень вважали статистично вірогідними при $\mathrm{P}<0,05-*$; $\mathrm{P}<0,002$ - **; $\mathrm{P}<0,01-$ $* * * ; \mathrm{P}<0,001-* * * *$.

\section{Результати та їх обговорення}

У ФГ ПП “Глиняни Агро” водопостачання централізованого типу, мережа наповнюється водою з підземного джерела, що забезпечує цілодобову подачу питної води. За допомогою насосної станції воду 3 глибини іiі залягання піднімають у резервуар водозабірної башти, з якої через водорозподільну систему, під тиском подають до тваринницьких приміщень. Для тварин облаштовують індивідуальні ніпельні напувалки, забезпечуючи вільний доступ до води.

Результати досліджень якості води з господарств наведені у таблиці 1. Прозорість питної води у ФГ ПП "Глиняни Агро" становила 30 см за шкалою Снеллена. Інтенсивність запаху, смаку та присмаку відповідала вимогам щодо цих показників. Окиснюваність води становила 0,008 мг $\mathrm{O}_{2}$ на 1 л води, а кількість розчиненого кисню - 2,58 мг $\mathrm{O}_{2}$ на 1 л, ці показники перебували в межах ГДК. Активна реакція води $\mathrm{pH}$ була в межах 6-7, вміст амонійного азоту становив 0,2 мг/л, вміст нітритів 0,002 мг/л, а нітратів $<0,001$ мг/л. Варто зазначити, що дане господарство не застосовує жодних методів очистки води, це суто природна за своїм походженням грунтова вода.

Концентрація хлоридів та сульфатів була в межах 1-10 мг/л, а Заліза - 0,15 мг/л. Твердість води: загальна -23 мг/екв. на 1 л, карбонатна - 8,3 мг/екв. на 1 л та постійна - 14,7 мг/екв. на 1 л, що вказує на достатньо високий рівень санітарного та хімічного складу води.

Своєю чергою водопостачання ферми ТзОВ "М'ясні ресурси" здійснюється 3 трьох вододжерел. Вода насосами транспортується в резервуар, відстоюється, фільтрується і через водорозподільчу систему постачається до кожної індивідуальної ніпельної напувалки.

Якість води у цьому господарстві (табл. 1) була дещо гіршою порівняно з попереднім господарством. Прозорість становила 16 см, що вказує на наявність завислих нерозчинених мінеральних чи органічних частинок. Запах досліджуваної води становив 2 бали, смак та присмак оцінено у 2 бали, оскільки слабо відчувається післясмак. Окислюваність води становила 2,8 мг/л, кількість розчиненого у ній кисню 6,75 мг/л, $\mathrm{pH}-7$. Встановлено наявність амонійного азоту - 0,2 мг/л, нітритів - 0,002 мг/л, а нітратів $<0,001$ мг/л. Дані показники вказують на те, що на відміну від попереднього господарства якість води не за всіма показниками відповідає гігієнічним вимогам і ставить під знак питання можливість іiі використання для напування свиней. Вміст хлоридів та сульфатів був дуже високим понад 100-150 мг/л відповідно, а вміст Заліза 1 мг/л, що могло вплинути на ії присмак. Загальна твердість води становила 41 мг/екв. на 1 л, що вказує на те, що вода в цьому господарстві дуже тверда. При порівнянні твердості води у ФГ ПП “Глиняни Агро” та ТзОВ “М'ясні ресурси” - в останньому загальна твердість води є у 1,8 разу більшою. Стосовно постійної твердості, то вона у 2,2 разу більша.

\section{Таблиця 1}

Санітарно-гігієнічна оцінка якості води для напування тварин

\begin{tabular}{lcc}
\hline \multicolumn{1}{c}{ Показник } & $\begin{array}{c}\text { ФГ ПП } \\
\text { “Глиняни Агро” “М'ясні ресурси” }\end{array}$ \\
\hline Прозорість, см & 30 & 16 \\
Запах, бали & 1 & 2 \\
Смак і присмак, бали & 1 & 2 \\
Окиснюваність, мг/л & 0,008 & 2,8 \\
К-ть розчиненого & 2,58 & 6,75 \\
кисню, мг/л & $6-7$ & 7 \\
Активна р-ція (рН) & 0,2 & 0,2 \\
Вміст амонійного & 0,002 & 0,002 \\
азоту, мг/л & $<0,001$ & $<0,001$ \\
Вміст нітритів, мг/л & $1-10$ & Понад 100 \\
Вміст нітратів, мг/л & $1-10$ & Понад 150 \\
Вміст хлоридів, мг/л & 0,15 & 1,0 \\
Вміст сульфатів, мг/л & 23 & 41 \\
Вміст Заліза, мг/л & & \\
Загальна твердість, & 8,3 & 8,5 \\
мг/екв. на 1 л & & \\
Карбонатна твер- & 14,7 & 32,5 \\
дість, мг/екв. на 1 л & & \\
Постійна твердість, & & \\
мг/екв. на 1 л & &
\end{tabular}

Отже, якість води в обох господарствах за результатами досліджень перебувала в допустимих санітарних і гігієнічних межах, хоча у ФГ ПП "Глиняни Агро” вона була значно вищою. Відхилення деяких показників від прийнятих норм $є$ результатом сукупних факторів, зокрема безпосередньо самого джерела води та облаштування іiі подачі до тваринницьких приміщень.

Аналіз мікрокліматичних показників, який наведений в таблиці 2, засвідчив, що влітку температура повітря у приміщеннях обох господарств була на однаковому рівні $23,07-23,7^{\circ} \mathrm{C}$. Абсолютна вологість повітря приміщення більшою була на 1,3 г/л більшою у ФГ ПП “Глиняни Агро”. Закономірно, що показник відносної вологості був на $4 \%$ більшим. У цей же період досліджень дефіцит насичення, хоч і не значно, 
був більшим у повітрі приміщень ТзОВ “М'ясні ресу-

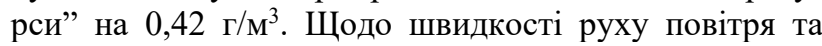
охолоджуючої його сили, то більшими ці показники були у приміщеннях ТзОВ “М'ясні ресурси" - на $0,05 \mathrm{~m} / \mathrm{c}$ та 0,64 мкал/ $\mathrm{cm}^{2} / \mathrm{c}$ відповідно. Стосовно концентрації аміаку, то найвище значення цей показник мав у ФГ ПП “Глиняни Агро”, що на 7,17 мг/м³ більше, ніж у ТзОВ “М’ясні ресурси”, та на 6 мг/м³ більше ГДК.
У перехідний період утримання закономірним було зниження температури повітря. Проте його параметри не відповідали гігієнічним вимогам. Так, у ФГ ПП "Глиняни Агро" температура повітря приміщення становила $10,28{ }^{\circ} \mathrm{C}$ при відносній вологості 93,6 \%, тимчасом як у приміщенні ТзОВ “М'ясні ресурси” температура повітря була на $3,16^{\circ} \mathrm{C}$ вищою при нижчій відносній вологості.

\section{Таблиця 2}

Показники параметрів мікроклімату у свинарниках ФГ ПП “Глиняни Агро" та ТзОВ “М'ясні ресурси" $(\mathrm{M} \pm \mathrm{m}, \mathrm{n}=9)$

\begin{tabular}{|c|c|c|c|c|}
\hline \multirow{3}{*}{ Показники } & \multicolumn{2}{|c|}{ Літній період } & \multicolumn{2}{|c|}{ Перехідні періоди } \\
\hline & $\Phi Г \Pi \Pi$ & $\mathrm{T}_{3} \mathrm{OB}$ & $\Phi Г \Pi \Pi$ & T3OB \\
\hline & “"Глиняни Агро” & "М'ясні ресурси" & “Глиняни Агро” & "М'ясні ресурси" \\
\hline Температура повітря, ${ }^{\circ} \mathrm{C}$ & $23,7 \pm 6,89$ & $23,07 \pm 0,05$ & $10,28 \pm 7,37$ & $13,44 \pm 9,59$ \\
\hline Абсолютна вологість, г/м ${ }^{3}$ & $11,06 \pm 0,16$ & $9,76 \pm 0,12$ & $7,66 \pm 6,96$ & $6,63 \pm 0,06$ \\
\hline Відносна вологість, \% & $50,61 \pm 0,70$ & $46,54 \pm 0,62$ & $93,6 \pm 5,24$ & $57,52 \pm 0,58$ \\
\hline Дефіцит насичення, г/м ${ }^{3}$ & $10,79 \pm 0,15$ & $11,21 \pm 0,14$ & $1,67 \pm 8,07$ & $4,87 \pm 8,07$ \\
\hline Ката-індекс, мкал /см²/ с & $4,04 \pm 0,04$ & $4,68 \pm 0,07$ & $8,86 \pm 0,12$ & $7,88 \pm 0,11$ \\
\hline Швидкість руху повітря, м/с & $0,07 \pm 0,004$ & $0,12 \pm 1,09$ & $0,11 \pm 5,53$ & $0,12 \pm 9,71$ \\
\hline $\mathrm{NH}_{3}, \mathrm{M} \Gamma / \mathrm{M}^{3}$ & $26,0 \pm 2,08$ & $18,83 \pm 1,16$ & $23,33 \pm 0,86$ & $17,33 \pm 1,45$ \\
\hline
\end{tabular}

Дефіцит насичення закономірно вищим був у ТзОВ “М'ясні ресурси”, але знаходився в межах гігієнічної норми. Швидкість руху повітря у приміщеннях обох господарств була майже однаковою, в межах 0,11-0,12 м/с, а охолоджуюча сила повітря, хоча лише на 0,98 мкал/см²/c, але більшою була у ФГ ПП “Глиняни Агро”. У цей же період досліджень концентрація аміаку в повітрі приміщення цього господарства була

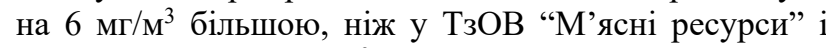
одночасно на 3,33 мг/м³ більшою за ГДК.

Загалом умови утримання поросят у господарствах, де проводились дослідження, далекі від ідеальних, мають потребу в корегуванні. Необхідні заходи щодо зниження вмісту аміаку в повітрі приміщень та заходи поліпшення якості води.
Дані таблиці 3 свідчать, що незважаючи на певні похибки умов вирощування, новонароджені поросята мають добру вагу: 1,11 кг у ФГ ПП “Глиняни Агро” та 1,07 кг у ТзОВ “М'ясні ресурси”. Закономірно, що у поросят цього господарства дещо меншим був середньодобовий приріст - на 6 г і відповідно на 200 г жива маса однісї тварини у 30-денному віці порівняно 3 поросятами ФГ ПП “Глиняни Агро”. Проте вже через 60 діб вирощування поросят різниця у вазі однієї тварини становила 1,7 кг на користь ТзОВ “М'ясні ресурси”, тому що в цей період на 0,063 кг були вищими середньодобові прирости. У 120 -добовому віці жива маса однієї тварини була більшою у ФГ ПП “Глиняни Агро" відповідно на 3 кг, у них же вищими були i середньодобові прирости.

\section{Таблиця 3}

Жива маса та середньодобові прирости молодняку свиней ФГ ПП “Глиняни Агро” та ТзОВ “М'ясні ресурси” $(\mathrm{M} \pm \mathrm{m}, \mathrm{n}=11)$

\begin{tabular}{|c|c|c|c|}
\hline Показник & Од. & $\begin{array}{c}\text { ФГ ПП } \\
\text { “Глиняни Агро” }\end{array}$ & $\begin{array}{c}\text { ТзОВ } \\
\text { "М'ясні ресурси" }\end{array}$ \\
\hline Жива маса новонародженого поросятка & Кг & 1,11 & 1,07 \\
\hline Жива маса 1тварини у 30-добовому віці & кг & 8,40 & 8,20 \\
\hline Приріст 1 тварини валовий & КГ & 7,29 & 7,13 \\
\hline середньодобовий & кг & 0,243 & 0,237 \\
\hline Жива маса 1тварини у 60-добовому віці & кг & 15,3 & 17,0 \\
\hline Приріст 1 тварини валовий & кг & 6,9 & 8,8 \\
\hline середньодобовий & кг & 0,230 & 0,293 \\
\hline Жива маса 1тварини у 120-добовому віці & КГ & 53,2 & 50,2 \\
\hline Приріст 1 тварини валовий & кг & 37,9 & 33,2 \\
\hline середньодобовий & кг & 0,631 & 0,553 \\
\hline
\end{tabular}

Стосовно гематологічних показників у поросят даних господарств (табл. 4), то у 30-добовому віці більша на 0,62 Т/л кількість еритроцитів була в крові тварин ТзОВ “М'ясні ресурси”. Ця тенденція збереглась i в 60-добовому віці поросят. Найбільшу кількість еритроцитів в крові встановили у поросят 120-добового віку, що на 0,84 T/л переважало показники ровесників з господарства ФГ ПП “Глиняни Агро”. 
Концентрація гемоглобіну хоча була низькою у тварин обох господарств, нижча за межу фізіологічної норми, проте вищі показники були у тварин ФГ ПП “Глиняни Агро" на 5,13 г/л та 3,52 г/л у 30- та 60добовому віці відповідно. Тенденція щодо концентрації гемоглобіну на користь тварин ФГ ПП “Глиняни
Агро” змінилась у 120-добовому віці, цей показник на 3,28 г/л був більшим у представників ТзОВ "М'ясні ресурси". Відповідно до значень кількості еритроцитів та концентрації гемоглобіну - i кольоровий показник.

\section{Таблиця 4}

Гематологічні показники та швидкість осідання еритроцитів молодняку свиней $(\mathrm{M} \pm \mathrm{m}, \mathrm{n}=11)$

\begin{tabular}{|c|c|c|c|}
\hline \multirow{2}{*}{ Показники } & \multicolumn{3}{|c|}{ Вік тварин, діб } \\
\hline & 30 & 60 & 120 \\
\hline \multirow{2}{*}{ Еритроцити, Т/л } & $\underline{5,70 \pm 0,62}$ & $5,91 \pm 0,30$ & $6,47 \pm 0,77$ \\
\hline & $\overline{6,32 \pm 0,31}$ & $6,57 \pm 0,23$ & $7,31 \pm 0,19$ \\
\hline \multirow{2}{*}{ Гемоглобін, г/л } & $\underline{78,57 \pm 6,95}$ & $\underline{85,27 \pm 1,03}$ & $89,6 \pm 2,17$ \\
\hline & $\overline{73,44 \pm 2,72}$ & $\overline{79,02 \pm 4,05}$ & $\overline{92,88 \pm 3,22}$ \\
\hline \multirow{2}{*}{ Гематокрит, \% } & $\underline{48,45 \pm 1,01}$ & $47,28 \pm 0,57$ & $\underline{42,81 \pm 0,85}$ \\
\hline & $38,83 \pm 0,77^{* * * *}$ & $40,72 \pm 0,85^{* * * *}$ & $38,36 \pm 0,57^{* * * *}$ \\
\hline \multirow{2}{*}{ КП, пг } & $\underline{45,54 \pm 5,60}$ & $43,06 \pm 0,58$ & $\underline{46,73 \pm 4,61}$ \\
\hline & $\overline{35,57 \pm 1,91}$ & $36,14 \pm 2,45^{* * *}$ & $\overline{38,47 \pm 1,80}$ \\
\hline \multirow{2}{*}{ COE, мкм ${ }^{3}$} & $\underline{83,93 \pm 10,82}$ & $80,11 \pm 0,66$ & $73,63 \pm 6,72$ \\
\hline & $\overline{62,29 \pm 4,30}$ & $\overline{62,52 \pm 2,16}^{* * *}$ & $\overline{52,94 \pm 1,97}^{* * *}$ \\
\hline \multirow{2}{*}{ ШОЕ, мм/ год } & $3,22 \pm 0,49$ & $3,86 \pm 0,38$ & $4,45 \pm 0,31$ \\
\hline & $2,30 \pm 0,13$ & $3,54 \pm 0,45$ & $4,36 \pm 0,26$ \\
\hline
\end{tabular}

Примітка: в чисельнику наведені дані ФГ ПП “Глиняни Агро”, в знаменнику - ТзОВ “М'ясні ресурси”

Гематокритна величина лише у поросят ТзОВ “М'ясні ресурси” перебувала у межах фізіологічної норми, ближче до верхньої іiї межі, тимчасом як у тварин ФГ ПП "Глиняни Агро" вона на 4-5,4 \% ii перевищувала. I лише у поросят 120-добового віку вона була на рівні верхньої межі фізіологічної норми.

Що стосується СОЕ, то цей показник лише у тварин ТзОВ “М'ясні ресурси" перебував у межах фізіологічної норми поросят усіх вікових періодів. У тварин ФГ ПП "Глиняни Агро" він перевищував верхню межу фізіологічної норми на $15,93,12,11$ та 5,62 мкм $^{3}$ відповідно. Зі збільшенням віку тварин СОЕ зменшу- вався у представників обох господарств. Різниця між віковими групами становила 21,$64 ; \quad 17,59$ та 20,69 мкм $^{3}$, відповідно у 30-, 60- та 120 -добовому віці.

Згідно 3 даними таблиці 4, показник ШОЕ у тварин двох господарств був у межах фізіологічної норми, ближче до ії нижньої межі в усі вікові періоди, чого не можна сказати про вміст загального протеїну та його фракцій. Одержані нами дані свідчить про його низький вміст у тварин обох господарств. Так, у 30 -добовому віці цей показник був на 11,99 г/л та 12,13 г/л меншим за нижню межу фізіологічної норми відповідно.

\section{Таблиця 5}

Вміст загального протеїну та протеїнових фракцій крові молодняку свиней $(\mathrm{M} \pm \mathrm{m}, \mathrm{n}=11)$

\begin{tabular}{|c|c|c|c|}
\hline \multirow{2}{*}{ Показники } & \multicolumn{3}{|c|}{ Вік тварин, діб } \\
\hline & 30 & 60 & 120 \\
\hline \multirow{2}{*}{ Загальний протеїн, г/л } & $\underline{58,01 \pm 1,16}$ & $\underline{57,26 \pm 1,20}$ & $\underline{67,27 \pm 4,03}$ \\
\hline & $\frac{0,91 \pm 1,36}{57,87 \pm 1,36}$ & $57,20 \pm 1,14$ & $68,61 \pm 0,66$ \\
\hline \multirow[b]{2}{*}{ Альбуміни, \% } & $18,54 \pm 3,17$ & $23,16 \pm 2,04$ & $\underline{31,32 \pm 1,45}$ \\
\hline & $24,33 \pm 3,91$ & $24,41 \pm 0,32$ & $32,07 \pm 1,92$ \\
\hline \multirow{2}{*}{ Глобуліни, \% } & $\underline{81,46 \pm 3,17}$ & $\underline{76,73 \pm 3,71}$ & $\underline{68,70 \pm 0,86}$ \\
\hline & $\frac{01,70 \pm 1,11}{75,67 \pm 3,98}$ & $\frac{10,10 \pm 0,11}{75,60 \pm 1,33}$ & $\frac{00,70 \pm 0,00}{67,93 \pm 0,66}$ \\
\hline \multirow{2}{*}{ а-глобуліни, \% } & $\underline{24,39 \pm 4,63}$ & $\underline{22,24 \pm 1,68}$ & $\underline{22,30 \pm 1,11}$ \\
\hline & $16,66 \pm 1,93$ & $16,90 \pm 0,74^{* * *}$ & $16,90 \pm 0,67^{* * * *}$ \\
\hline \multirow{2}{*}{$\beta$-глобуліни, \% } & $19,02 \pm 2,34$ & $16,02 \pm 1,61$ & $18,30 \pm 0.76$ \\
\hline & $29,65 \pm 4,19^{*}$ & $25,44 \pm 1,49^{* * * *}$ & $23,45 \pm 1,70^{* * *}$ \\
\hline \multirow{2}{*}{ ү-глобуліни, \% } & $38,05 \pm 3,65$ & $\underline{39,30 \pm 1,02}$ & $28,10 \pm 1,67$ \\
\hline & $29,36 \pm 4,46$ & $33,30 \pm 1,63^{* * *}$ & $27,58 \pm 0,71$ \\
\hline
\end{tabular}

Примітка: в чисельнику наведені дані ФГ ПП “Глиняни Агро”, в знаменнику - ТзОВ “М'ясні ресурси”

У поросят 60-добового віку вміст загального білка, таблиця 5, зменшувався і мав тенденцію до зростання лише до 120 доби життя поросят. В цей період вміст білка в крові поросят зріс на 10,01 та 11,41 г/л порівняно 3 попереднім періодом i був наближений до нижньої межі фізіологічної норми, але не перевищував іii. В цей віковий період у поросят було порушене альбуміно-глобулінове співвідношення. Відсоток глобулінової фракції білка був значно більшим за фізіологічну норму у тварин обох господарств в усі 
вікові періоди, переважно за рахунок $\alpha$ - та $\gamma$ глобулінів у поросят ФГ ПП "Глиняни Агро", тимчасом як у поросят ТзОВ “М'ясні ресурси" перевага глобулінової фракції була за рахунок усіх трьох іiі складових. Аналізуючи відсоток $\gamma$-глобулінів, доречно наголосити, що ця фракція значно перевищувала верхню межу фізіологічної норми, а особливо у тварин ФГ ПП “Глиняни Агро”.

\section{Таблиця 6}

Показники клітинного імунітету крові молодняку свиней $(\mathrm{M} \pm \mathrm{m}, \mathrm{n}=11)$

\begin{tabular}{|c|c|c|c|}
\hline \multirow{2}{*}{ Показники } & \multicolumn{3}{|c|}{ Вік тварин, діб } \\
\hline & 30 & 60 & 120 \\
\hline \multirow{2}{*}{ Т- лімфоцити, \% } & $\underline{40,91 \pm 0,66}$ & $\underline{43,45 \pm 1,09}$ & $45,27 \pm 1,07$ \\
\hline & $\overline{41,41 \pm 0,64}$ & $\overline{43,72 \pm 1,23}$ & $47,09 \pm 1,47$ \\
\hline \multirow{2}{*}{ Т- хелпери, \% } & $23,50 \pm 0,93$ & $25,54 \pm 1,42$ & $27,63 \pm 0,72$ \\
\hline & $23,33 \pm 0,75$ & $26,72 \pm 1,27$ & $28,18 \pm 1,08$ \\
\hline \multirow{2}{*}{ Т- супресори, \% } & $17,41 \pm 0,48$ & $17,45 \pm 0,34$ & $\underline{18,27 \pm 0,57}$ \\
\hline & $\overline{18,08 \pm 0,41}$ & $\overline{18,27 \pm 0,50}$ & $\overline{19,18 \pm 0,35}$ \\
\hline \multirow[b]{2}{*}{ Т- натур.кіллери, \% } & $13,66 \pm 0,41$ & $14,09 \pm 0,31$ & $\underline{15,09 \pm 0,65}$ \\
\hline & $13,41 \pm 0,31$ & $14,36 \pm 0,27$ & $14,18 \pm 0,29$ \\
\hline \multirow{2}{*}{ В- лімфоцити, \% } & $\underline{14,41 \pm 0,41}$ & $\underline{15,18 \pm 0,55}$ & $\underline{18,45 \pm 0,62}$ \\
\hline & $\overline{15,08 \pm 0,45}$ & $\overline{15,72 \pm 0,48}$ & $\overline{18,36 \pm 0,54}$ \\
\hline \multirow{2}{*}{ IPI, \% (Т-хелп./Т-супрес.) } & $\underline{1,37 \pm 0,09}$ & $\underline{1,44 \pm 7,39}$ & $\underline{1,48 \pm 4,28}$ \\
\hline & $1,30 \pm 6,35$ & $1,46 \pm 0,06$ & $1,46 \pm 4,86$ \\
\hline
\end{tabular}

Примітка: в чисельнику наведені дані ФГ ПП “Глиняни Агро”, в знаменнику - ТзОВ “М'ясні ресурси”

Щодо показника клітинного імунітету крові молодняку свиней 3 обох господарств, що поданий в таблиці 6, то вміст Т-лімфоцитів був значно меншим за нижню межу фізіологічної норми і в 30-, і в 60добовому віці. І тільки у 120-добовому віці збільшувався, проте у поросят ФГ ПП "Глиняни Агро" лише на $0,27 \%$ перевищував нижню межу фізіологічної норми, тимчасом як у аналогів з ТзОВ “М'ясні ресурси" - на 2,09 \%. Кількість Т-хелперів та Т-супресорів перебувала на нижній межі фізіологічної норми в усі вікові періоди тварин обох господарств. Дещо вищі показники були у тварин з ТзОВ “М'ясні ресурси”, зі збільшенням віку тварин спостерігалась тенденція до їх зростання.

Стосовно Т-натуральних кіллерів, то цей показник не мав чіткої тенденції і коливався у різних вікових груп тварин з господарства ТзОВ “М'ясні ресурси”. В 60-добовому віці відмічено його зростання порівняно з 30-добовими на $0,95 \%$ і зменшення на $0,18 \%$ до 120-добового віку. У тварин з ФГ ПП "Глиняни Агро" спостерігалася стійка тенденція хоч і не до значного, але зростання цього показника.

Визначення відношення Т-хелперів до Тсупресорів (IPI) засвідчило, що цей показник був на рівні фізіологічної норми у тварин 60- та 90-добового віку з обох господарств. Нижчим за фізіологічну норму цей показник був на початку досліджень у поросят 30-добового віку.

\section{Висновки}

Результати проведених досліджень ще раз підтверджують, що на ріст, розвиток, продуктивність тварин впливає сума факторів як гігієнічного, так і технологічного спрямування. Господарства, в яких утримували поросят мали певні недоліки в технологічному процесі, це зокрема щодо параметрів мікроклімату, якості води та способів іiі забору і постачання у тва- ринницькі приміщення. Суттєвою різницею було однофазне утримання в ФГ ПП "Глиняни Агро" та трифазне у ТзОВ “М'ясні ресурси”.

Незважаючи на те, що поросята в обох господарствах народжувались 3 вагою 1,11 кг та 1,07 кг відповідно, проте гематологічні показники, зокрема концентрація гемоглобіну в них була меншою за нижню межу фізіологічної норми. Низьким були показник вмісту загального протеїну, порушене альбуміноглобулінове співвідношення (низький відсоток альбумінів), а також рівень клітинного імунітету поросят. Ці дані показали, що однофазне вирощування поросят $\epsilon$ значно ефективнішим у плані мінімізації стресових ситуацій, проте і в ФГ ПП "Глиняни Агро", і в ТзОВ "М'ясні ресурси" необхідно провести корегувальні заходи щодо підвищення імунного статусу поросят та його зміцнення.

Перспективи подальших досліджень. Одержані результати досліджень впливу якості води, технології утримання та мікроклімату на зміни живої маси тіла та середньодобові прирости, гематологічні, біохімічні та імунологічні показники молодняку свиней спонукають до подальшого проведення ряду досліджень, спрямованих на пошук нових методів для корегування та зменшення негативного впливу технологічних стресів на функціональний стан організму тварин.

\section{References}

Anush, Z. (1979). Hihiena vody v zhyvotnovodstve. Per. z pol. Miroshnichenko H.N.; Pod. red. Mychko S.A. Kolos, 1979. 192 p.(in Russian).

Chornyi, M. V., \& Khomutovska, S. O. Sanitarnohihiienichne znachennia fermy $\mathrm{V}$ konteksti profilaktyky khvorob svynei. Veterynarna medytsyna, 97, 486-489 (in Ukrainian). 
Demchuk, M. V., Chornyi, M. V., Zakharenko, M. O., \& Vysokos, M. P. (2006). Hihiiena tvaryn: Pidruchnyk. Druhe vydannia. Kharkiv (in Ukrainian).

DSTU 4808:2007. Dzherela tsentralizovanoho pytnoho vodopostachannia. Hihiienichni ta ekolohichni vymohy shchodo yakosti vody i pravyla vybyrannia. https://www.twirpx.com/file/2048754 (in Ukrainian).

DSTU 7525:2014. Natsionalnyi standart Ukrainy. Voda pytna. Vymohy ta metod kontroliu yakosti. https://www.twirpx.com/file/1908715 (in Ukrainian).

Goryaev, D. V., Tikhonova, I. V., \& Torotenkova, N. N. (2016). Hygienic assessment of drinking water quality and risks to public health in Krasnoyarsk region. Health Risk Analysis, 3, 35-43. doi: 10.21668/health.risk/2016.3.04.eng.

Harytskyi, V. O., \& Rozumniuk, A. V. (2007). Vplyv parametriv mikroklimatu na zdorovia ta produktyvnist porosiat. Naukovyi visnyk LNUVM imeni S. Z. Hzhytskoho, 9, 1(32), 36-38 (in Ukrainian).

Hryhorenko, L. (2015). Ecological \& hygienic assessment of potable water quality in the Kryvyi Rih district.
Medical Science, Pharmacology, 8, 15-17. doi: 10.18007/gisap:msp.v0i8.1117.

Ievtushenko, M. Iu., \& Dudnyk, S. V. (2016). Vodna toksykolohiia: Pidruchnyk. Kherson: OLDI-PLIuS (in Ukrainian).

Kelly, E. R., Cronk, R., Kumpel, E., Howard, G., \& Bartram, J. (2020). How we assess water safety: A critical review of sanitary inspection and water quality analysis. Science of The Total Environment, 718, 137237. doi: 10.1016/j.scitotenv.2020.137237.

Tkachuk, O. D. (2010). Vplyv mikroklimatu na osnovni pokaznyky rezystentnosti svynei. Visnyk Poltavskoi derzhavnoi ahrarnoi akademii, 2, 136-140 (in Ukrainian).

Zahalnoderzhavna prohrama "Pytna voda Ukrainy" na 2011-2020 roky. Zakon Ukrainy vid 20 zhovtnia 2011 r. № 3933-VI. Vidomosti Verkhovnoi Rady Ukrainy, 2012. № 24. P. 247 (in Ukrainian).

Zapolskyi, A. K. (2005). Vodopostachannia, vodovidvedennia ta yakist vody: Pidruchnyk. K.: Vyshcha shkola (in Ukrainian). 